\title{
Diels-Alder反応一一微生物二次代謝物 生合成への関与
}

Diels-Alder 反応（DA）は有名なWoodward-Hoffmann の轨道対称性保存則の好例であり, ジェンとジェ ノフィル（モノェン）から六員環を形成する反応であ る. DA は前記の法則に従い, 高い立体選択性を示すこ とから有機合成上最も有用な反応の一つである(1). 一般 には基底状態で非触媒的に起こる熱的な反応として知ら れていることから，本反応を触媒する酵素があるという こと自体奇異に感じる方も多いのではないだろらか。す でに, 生体には DA と同様ペリ環状反応の一種である Claisen 転移反応を触媒する chorismate mutase が知 られることからここした反応が天然に存在しても不思 議はないと言えるう、筆者は植物病原菌の生産する毒素 の構造研究から本反応の生合成への関与に興味を持ら, 研究を行なってきたが，今回筆者以外の研究も含酵亲 反応の可能性があるものを中心に紹介したい。

問題とする化合物が DA により生合成されたとする ときの主な根拠には，以下に揭げるようなるのがある。 (1)存在するシクロへキサン環を開裂させたとき，天然に 見られる構造単位に行き当たる. (2) DA によって生成 可能な複数の異性体または想定される基質が同一の生物 より単離される. (3)問題となる化合物が不斉中心を有す るとき，光学活性体である. 天然物の中にこうした [4 ＋2】付加体があることを記した論文は 1960 年代前半に はすでに見られ，菌由来ではないが、テルペンの二量体で ある maytenone, kitol といった例が報告されている(2).

天然物由来の DA 付加物には分子間㐨よび分子内反 応生成物の 2 種があり，前者はさらに同一基質の二量体 と異なる 2 種の基質由来の付加物に分けられる(2). 最 初微生物代謝産物以外の例も含め，具体的な例をあげ る.
沖縄産カイメンより単離された ageliferin（1）は分子 間反応生成物であり，同時に単離される hymenidin (2) の二量体と考えられる(3).これは 2 亿不斉中心がなく， 1 は光学活珄体であることから，酵素的 DA 生成物と 推測される. また野村らによりクワ根皮から多数のDA 付加体が単離されている(4).この中に mulberrofuran C (3)があるが，これは植物成分としてはよく知られている chalcone とプレニル化された arylbenzofuran から付加 物を与えたものと考劣られる。この場合には 3 の立体異 性体である 4 も同時に単離されており，上記の条件をす べて満たしている，事実，生合成中間体類似体の取り込 及実験の結果は DA の関与を強く支持している. 系状 菌代謝産物 flavoskyrin 5 はありふれた構造単位である anthaquinone の二量体であるが、これはジェン部に酸 素原子が含まれるへテロ DA の例と考光ることができ る(亏).この他，DA 付加物と予想される多くのリグナン 類が知られるが，すべて光学不活性であることから酵素 関与の可能性は低い、(6).

分子内 DA の例としては微生物由来のポリヶタイド 経路で生合成される化合物が多く知られ, HMG-CoA 還 元酵素阻害剂として知られる mevinolin, 放線菌の生産 する抗生物質 nargenicin $\mathrm{A}_{1}$ などは，構成原子の由来を 明らかにする取り込み実験結果をもとに DAを経る生 合成経路が提出されている(7)，これらは1本のポリケタ イド鎖由来の直鎖状中間体想定しており，これにジェ ンとモノェンが適当な位置にあり，環化することによっ てデカリン環が形成される場合が多い. 分子内 DA K ついては後で詳しくふれたい.ニショウ科の植物より cyclopiperstachine (6) 抢よびその環化前の前駆体と考 えられる piperstachine (7) が得られたが(8)，6 はラセ ミ体であり，非酵素的に環化したことも完全に否定でき ない，この論文では低極性有機溶媒中での 7 のAに 

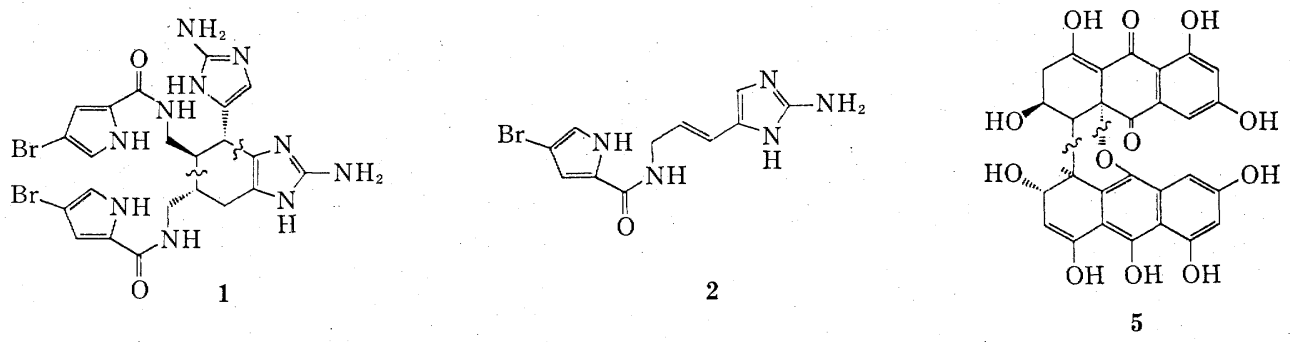<smiles>CC(C)=CC(=CC(=O)c1ccc(O)cc1O)c1ccc(O)cc1O</smiles><smiles>CC(C)CNC(=O)[C@@H]1[C@@H](c2ccc3c(c2)OCO3)C=C[C@H]2CCCC[C@@H]21</smiles>

6<smiles>CC(C)CNC(=O)/C=C/CC/C=C/C=C/c1ccc2c(c1)OCO2</smiles>

7

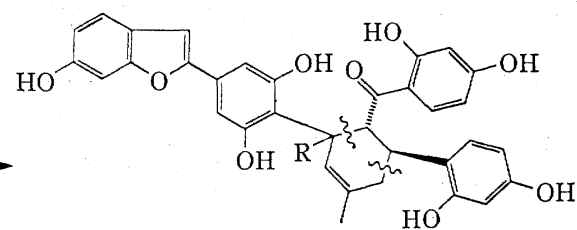

$3 \mathrm{R}=\beta-\mathrm{H}$

$4 \mathrm{R}=\alpha-\mathrm{H}$<smiles>C/C=C/C=C\CCCC/C=C/c1cc(OC)c(C=O)c(=O)o1</smiles>

10
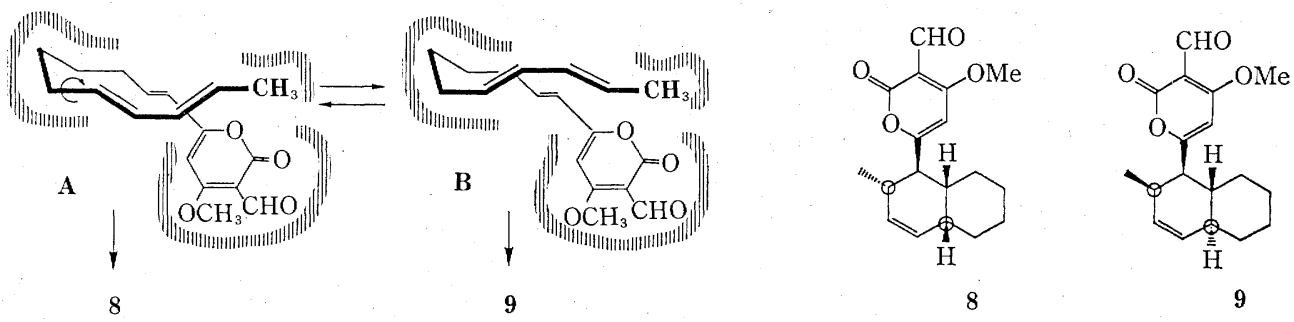

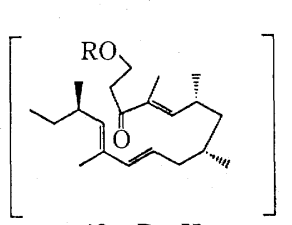

13a $\mathrm{R}=\mathrm{H}$

13b $\mathrm{R}=\mathrm{CH}_{3}$

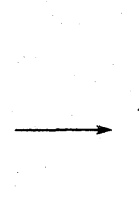

(N)

12

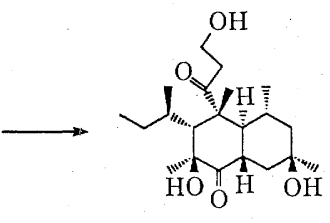

11

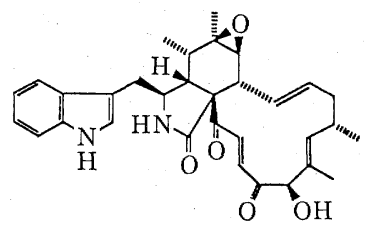

14
$=$

15

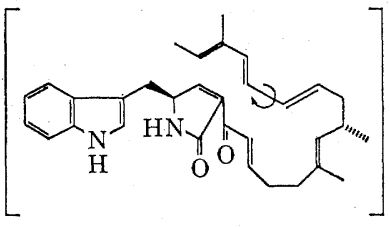

16

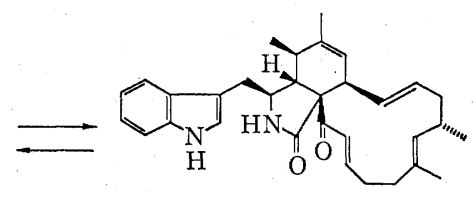

17 
要する温度は高く, 抽出操作中に生成した artifact では ないとしている．これについては環化酵素が 2 種類あ り，それぞれが等量の生成物を与えるとは考兄にくく，

Breslow は非極性有機溶媒, 水々反応溶媒を変光たとき に DA の反応速度が劇的に異なる例を紹介して括り(9)， むしろ溶媒の違いやルイス酸として触媒作用をする物質 の存在なども考慮しなければならないだろう。またカチ オンラジカル経由の DA も知られていることから(10), その活性種を生成させる酵素があるのかむしれない。

以下に, 糸状菌由来のポリヶタイド化合物についての 分子内 DAを扱った例を紹介する.

バレイショ夏疫病菌 Alternaria solani が生産する毒 素に solanapyrone A(8)があるが，この化合物はその生 合成研究から 8 個の酢酸と 2 個のメチオニン由来の $\mathrm{C}_{1}$ 単位からなるポリケタイド化合物である(11)。本菌から 8 の立体異性体 solanapyrone $\mathrm{D}(\boldsymbol{9})$ も単離されたが，これ は DA によって生成可能な 2 種の異性体が得られたこ とになりこれらは $[4+2]$ 環化により生合成すること が示唆された．興味あることに，上記の化合物は想定さ れる前駆体 10 が光学不活性であるにもかかわらず，と もに光学活性体として得られたことから, 酵素の関与が 考兄られた. 化合物 8 と 92 籄所の立体化学が反転し て抒り, ジェン部, ジェノフィル部のいずれの由来のも のが変わっているのか, 酵素の認識との関わりから興味 が持たれた。

筆者らは, 両方の化合物を安息香酸誘導体に導き, 円 二色性スペクトル法から絶対配置を決定したところ, ジ エン部の立体化学が反転していることがわかり,このこ とから図に示したよらに酵素の認識機構に関する仮説を 提出した ${ }^{(12)}$.すなわち，酵素はジェノフィル部は厳密に 識別するが，ジェン部については単結合の回転により相 互变換可能な A， B 2 種の遷移状態を緩やか汇認識する ため，双方から異なる生成物を与える，というもので㐫 る. 両方の遷移状態に大きなエネルギー差がないことは 類縁体の DA に打いて医济1：1の比で両異性体を与 えることからも支持された. 最近, 前駆体 10 と酸化度 の異なる標識仮想中間体の菌への投与実験から, 本反応 が実在する証拠を得て和り, 今後生体内 DA の実体が 明らかになっていくものと思われる。

この他, DA 環化後酸化的修飾を受け, 見かけ上他の 生合成経路が考光られるものもある。テンサイ蛇眼病菌
Phoma betae の産生する植物毒素 betaenone B (11) は ポリケタイド化合物であるが，アルドール型の縮合によ り生合成されるのか，DAを経るのか判別できなかった。 取り込み実験により酸素原子の由来を明らかにし，さら に酸化酵素の阻害剤を添加した培盖でまったく酸化を受 けていない 12 が単離できたことから，DA 経由すると いら有力な証抛を得た ${ }^{(13)}$. 興味あることに，仮想環化前 駆体 13 a の類縁体 $13 \mathrm{~b}$ 浰による環化でも単一の生成 物を与える。これは生物が基質をうまく設計し，反応の 選択性を上げた例とはいえないだろうか。一方，マイコ トキシン chaetoglobosin A(14) も何段階かの酸化を受 けているため，DA の直後の前駆体を特定できなかった が, 前述の阻害剂実験で予想環化前駆体 15 が単離でき た(14).この物質が中間体である証明はまだなされていな いが，化合物 15 をA の逆反応である熱反応に付すと 開環体 16 は検出されず，15 の立体異性体である 17 が 単離された ${ }^{(15)}$. cytochalasin と呼ばれる 14 と類似のマ イコトキシンの全合成研究でも DA による大員環 の構 築では立体選択性が高くなく(16)，この場合も一方の遷移 状態を酵素が安定化することで単一の化合物を作ってい ると考えた汇らがよさとうである.

誌面の都合で他の天然由来 DA 付加体の例は割 愛さ せていただくが, 最近, 抗生物質, 植物・海産動物由来 のテルペノイドの中数多く見いだされている．DA が これまで生体での存在が証明されなかったのは本反応が 一次代謝産物の生合成に関わっていなかったためと想像 される. $[4+2]$ 環化は従来の生体反応では類を見ない 炭素一炭素結合反応であり，これを触媒する酵素につい ての興味は尽きない，今後 DA が酵素レベルで解明さ れてゆくことを期待したい。

1) J. March : "Advanced Organic Chemistry", $3 \mathrm{rd}$ ed., Wiley, New York, 1985, p. 745.

2) A.C. Bazan, J.M. Edwards \& U.Weiss : Tetrahedron, 34, 3005 (1978).

3）小林淳一, 津田正史, 菊地由美子, 神田扶由子, 石橋正己, 大泉 康, 村山哲也, 程 傑飛, 太田富久, 野副重男, 佐 々木环磨: 第 32 回天然有機化合物討論会講演 要 旨集, 1990, p. 135.

4）野村太郎：ファルマシア，27，552 (1991).

5) S. Seo, U. Sankawa, Y. Ogihara, Y. Iitaka \& S. Shibata : Tetrahedron, 29, 3721 (1973).

6) 合成例 として, 山村庄亮: 有機合成化学協会誌， 43，583 (1985). 
7) R. N. Moore, G. Bigam, J. K. Chan, A. M. Hogg, T. T. Nakashima \& J.C. Vederas : J. Am. Chem. Soc., 107, 3694 (1985) ; D. E. Cane \& C.-C. Yang: J. Am. Chem. Soc., 106, 784 (1984).

8) B.S. Joshi, N. Viswanathan, D. H. Gawad \& W.von Philipsborn : Helv. Chim. Acta, 58, 1551 (1975) ; B.S. Joshi, N. Viswanathan. D. H. Gawad, V. Balakrishnan \& W. von Philipsborn : Helv. Chim. Acta, 58, 2295 (1975).

9) R. Breslow : Acc. Chem. Res., 24, 159 (1991).

10) N. L. Bauld : Tetrahedron, 45, 5307 (1989).

11) H. Oikawa, T. Yokota, T. Abe, A. Ichihara, S. Sakamura, Y. Yoshizawa \& J.C. Vederas : J. Chem. Soc., Chem.
Commun., 1989, 1282.

12) H. Oikawa, T. Yokota, A. Ichıhara \& S. Sakamura : $J$. Chem. Soc., Chem. Commun., 1989, 1284.

13) H. Oikawa, A. Ichihara \& S. Sakamura: J. Chem. Soc., Chem. Commun., 1988, 1284; 1990, 908.

14) H. Oikawa, Y. Murakami \& A. Ichihara : Tetrahedron Lett., 32, 4533 (1991) ; J. Chem. Soc., Perkin Trans. I, 1992, 2949.

15) H. Oikawa, Y. Murakami \& A. Ichihara: J. Chem. Soc., Perkin Trans. I, 1992, 2955.

16) E. J. Thomas : Acc. Chem. Res., 24, 229 (1991).

(及川英秋, 北海道大学農学部)

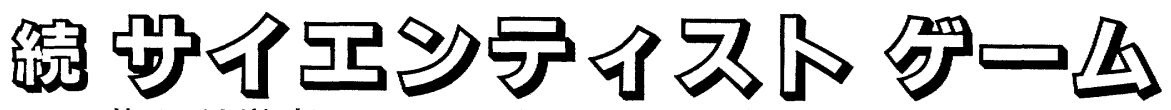

若き科学者のための生き残り戦略

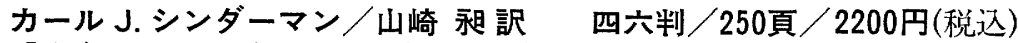

「サイエンティストゲームー成功への道」に続く，若き科学者の自己啓発のための指針。 科学者の世界も 1 つの社会である. 象牙の塔の中での立居振舞いと人間関係の調整, いか にして指導教授とうまくやっていくか, テーマの選択から論文の作成・発表に至る過程の 巧みな処理, 種々の転機をいかに乗り超えるか, 研究費捻出のノウハウ等々. プロを目指' す科学者のためのもう 1 つの科学論.
プロローヷ
1. 一人前と呼ばれるまでに
2. 象牙の塔の中での立居振舞い
3. キ三は指導教授とうまくやつているか
4. 賢明なる女子大学院生
5. 舞台の上の若手の科学者
6. 舞台裏での若き科学者
7. 若き科学者の小規模の会合

8. 人世の節目を生き残るために

9. 募集を応募

10. 科学の仕事場の特性

11. 科学における知的な取引と妥協

12. 科学のプロフェッショナルファサード

13. 信頼されること

14. 科学者の役割の变化

エピローブ

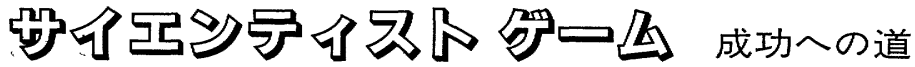

C.J! シンダーマン/山崎昶訳四六判 $/ 300$ 頁 $/ 2200$ 円(税込)

著者シンダーマン博士の「若き科学者の自己啓発のためのハンドブック」ともいうべき三部作の第 一作. 1990年代に向けてきびしい「科学」の世界でいかにして勝ち残るか. これから科学の社会に 進む若き学徒や転機を迎えた科学者各位のための優れた教訓やガイドラインが, 著者の長年の経験 や調査に裏付けられた酒脱なエピソードを含めて語られる. 